\title{
BEGINNING WITH PROPERTY? HEGEL AND UNFOLDING FREEDOM IN A SOUTH AFRICAN ACADEMIC CONTEXT
}

Author:

J. Sands ${ }^{1}$

\section{Affiliation:}

${ }^{1}$ Postdoctoral Fellow School for Philosophy

North-West University

Potchefstroom Campus

\section{Correspondence to:}

Justin Sands

Email:

justin.sands@nwu.ac.za

\section{Postal Address:}

Justin Sands c/o School for Philosophy

North-West University

Potchefstroom Campus

Private Bag X6001/Internal Box

208

Potchefstroom 2520

\section{Dates:}

15 Dec. 2016

\section{How to cite this article:}

Sands, J, 2016. "Beginning with Property? Hegel and Unfolding Freedom in a South African Academic Context". KOERS - Bulletin for Christian Scholarship, 81(3). Available at: https://doi.org/10.19108/ KOERS.81.3.2271

\section{Copyright:}

(C) 2016. The Author(s).

Published under the Creative Commons Attribution License.
Academic freedom is one of the most needed of all rights for a university to fulfil its mission to educate and uplift its students and, by extension, the society in which it lives. However, the question of what this freedom is and what it entails constantly unfolds as universities evaluate, critique, and educate society and this is at present under the microscope in the context of the \#feesmustfall campaign and other the student protests over social transformation. In the article I critique Hegel's concept of freedom, often considered one of the cornerstones to the philosophical foundation of Western society's concept of freedom, which was also employed within a South African context. From this, it is possible to gain a sense that this freedom entails a mutual recognition of the other and a responsibility to restrain one's own determination (or will-to-power) in order to ensure that the other does the same. Hegel reaches a stage where individuals mutually relinquish certain freedoms (like the freedom to kill or enslave another), and thus they create a space of mutual recognition where each sees the other as an individual self. This concept of freedom allows the university to remain solely on its own in the name of its academic freedom. The state recognizes this freedom as long as this relationship is mutually beneficial. The interference in the university's right to self-determination is indicative of a much larger issue. Although Hegelian freedom enjoins a respect between individuals within society, it can also be used to separate society; the 'we' disintegrates in light of so-called 'respect' when one wants to exert their right to autonomy at the expense of others. What I attempted to carve out is a critique of Hegelian freedom and its underpinning of the basic concept of freedom for both the Western and South African societies. By adding four more pillars to the Hegelian three - democracy, equality, reconciliation and diversity - South Africa has already begun to see that the issue could resolve itself with beginning to understand itself through more responsibility, respect, freedom and so forth.

KEYWORDS: academic freedom, \#feesmustfall campaign, Hegel's concept of freedom, respect, the state

Akademiese vryheid is een van die noodsaaklikste van al die regte wat ' $n$ universiteit nodig het om sy missie te vervul om sy studente op te hef en deur ' $n$ uitbreiding hiervan die gemeenskap waarin hulle hulle bevind ook op te hef. Die vraag is nou wat hierdie vryheid behels soos wat universiteite evalueer, kritiseer en opvoeding bied aan die samelewing. Dit is tans onder die loep binne die konteks van die \#feesmustfall veldtog en ook ander studente-proteste oor sosiale transformasie. In hierdie artikel ondersoek ek die konsep van vryheid soos deur Hegel gekonseptualiseer, aangesien dit dikwels gesien word as een van die hoekstene van die filosofiese fondamente van die Westerse opvatting van vryheid, wat ook binne die Suid-Afrikaanse konteks toepassing vind. Hieruit is dit moontlik om ' $n$ wederkerige erkenning van die ander kry, en dit behels ' $n$ verantwoordelikheid om mens se eie wilsdeterminasie te beperk om sodoende seker te maak dat die ander dieselfde sal doen. Hegel bereik ' $n$ stadium waar individue gelyktydig sekere vryhede afstaan (soos die vryheid om 'n ander in slawerny te neem of dood te maak) en dus skep hulle ' $n$ ruimte van wederkerige erkenning en sien mekaar as ' $n$ individuele self. Hierdie opvatting van vryheid laat die universiteit toe om op sy eie te bly staan in die naam van akademiese vryheid, en die staat laat dit toe solank hierdie Vryheid wedersyds tot voordeel strek. Die inmenging in die universiteite se reg tot self-determinasie is ' $n$ aanduiding van ' $n$ veel groter probleem. Hoewel Hegeliaanse vryheid poog om respek af te dwing tussen individue binne die samelewing kan dit ook gebruik word om die samelewing te versplinter sodat die "ons" disintegreer in die lig van sogenaamde "respek" as die een party sy reg tot outonomie wil afdwing tot nadeel van ander. Wat ek probeer uitwys het is ' $n$ kritiese beskouing van Hegel se konsep van vryheid en die onderliggendheid daarvan aan die basiese konsep van Vryheid vir beide die Suid-Afrikaanse en Westerse samelewings. Deur vier meer pilare toe te voeg tot die Hegeliaanse drie - demokrasie, gelykheid, versoening en diversiteit - het Suid-Afrika reeds begin sien dat begrip kan manifesteer deur verantwoordelikheid, respek, vryheid ensovoorts.

SLEUTELWOORDE: akademiese vryheid, \#feesmustfall veldtog, Hegel se konsep van vryheid, respek, die staat 


\section{INTRODUCTION}

Academic freedom is one of the most needed of all rights for a university to fulfil its mission to educate and uplift its students and, by extension, the society in which it lives. However, the question of what this freedom is and what it entails constantly unfolds as universities evaluate, critique, and educate society. Naturally, this becomes a tense relationship as academics attempt to push society while, in turn, the broader society attempts to keep the university grounded in the present concerns and questions that its individuals face daily. If academics stray too far from these problems, disregarding them in the name of an ersatz freedom to research, then they lose their connection to society and, hence, their mission. Correspondingly, when society begins to disregard the work of academics in the name of an ersatz freedom from elitism, they cease any real progress of addressing their individual and collective concerns. In this way, academic freedom does not entail autonomy; rather, it entails a mutual responsibility. In the current academic climate, South African universities are grappling with the question of freedom after 2015's \#feesmustfall campaign and other the student protests over social transformation - some of which have become violent as could be seen with the burning of campus buildings and other property at North-West University's Mafikeng Campus and at the University of Cape Town, to name just two examples. More pointedly, the issues surrounding the teaching and publishing languages within the university system directly concern the question of academic freedom: does the university adhere to the protests of (mostly black and under-privileged) students who do not want their universities teaching in Afrikaans or do they, in the name of academic freedom, resist this demand?

The split between Belgium's KU Leuven, my alma mater, and Louvain La-Neuve is a profound example of how academic autonomy, rather than freedom, can have negative consequences for both parties. The University of Louvain, established in 1425, flourished throughout its early and mid-life as one of Europe's premier universities. Within the mid-2oth century, when Belgium's linguistic-cultural divide began to sharpen with northern Flanders speaking Flemish-Dutch and southern Wallonia speaking French, the university was in crisis. As both regions began to further culturally separate themselves by language, Louvain, which is in the Flemish region, staunchly remained a French-speaking university. They published in French and taught in French. This relationship between the university and Flemish culture eventually deteriorated in the 1960s when students protested over their university's devotion to French education. By 1969, the university had officially become Flemish-speaking, renamed as Katholieke Universiteit Leuven. Outraged, several French-speaking professors left and founded what is now known as Louvain La-Neuve. In so doing, they took half of the university's books, with some series running A-M at Leuven and N-Z at Louvain La-Neuve, amongst other resources. Even though relations have softened today, this separation remains intact and what little cooperation there is between them is fraught with politics. Interestingly, KU Leuven's desire to internationalize eventually resulted in it embracing English as the primary publishing and teaching language. During my studies, I was even dissuaded from studying Flemish, encouraged to learn German instead and, ironically, French. Louvain La-Neuve, being firmly situated within francophone academia, still remains steadfastly French.

Even though both universities are well regarded institutions, one has to wonder what opportunities were lost in the duplication of libraries, professorships, staff, buildings, and so on. Furthermore, and most importantly, Louvain's professors failed to challenge society and to find resolutions to the growing divide between Flanders and Wallonia; a divide that, while peaceful, still exists today. Through a desire to have autonomy, to remain French while their students and country were rapidly changing, several academics decided to leave the conversation completely and to take with them valuable intellectual and institutional resources. Likewise, the protestors failed to recognize the historical-cultural situation of the university itself; thinking that it should immediately reflect its own values through language even though it had been a French speaking university and its francophone tradition stretched back over 400 years (in its earlier years, Latin was the teaching language). This divorce between the two was the result of a failure to communicate, but, more pointedly, it was a failure of responsibility in the name of 'freedom' on both sides.

In South Africa, I see a similar situation occurring within the language debate and the student protests at various universities where each side seeks certain autonomies, entrenched by a collective and individual will-to-power, where the term of 'freedom' is levied as a legitimizing force. However, this issue is not germane just to South African academia and society; one can see it in the so-called 'religious freedom' debates in the US, where some Christians reject the government's new laws pertaining to LGBT rights and health care mandates, as well as in Europe where right-leaning separatists seek more and more autonomy from the European Union. The United Kingdom's socalled 'Brexit' referendum is the chief example of this desire for ersatz freedom, or, more nakedly, autonomy. The issue ahead of South Africa and for the world at large is whether freedom means collective responsibility or individual autonomy.

In what follows, I will critique Hegel's concept of freedom, often considered one of the cornerstones to the philosophical foundation of Western society's concept of freedom, which was also employed within a South African context. From this, we will gain a sense that this freedom entails a mutual recognition of the other and a responsibility to restrain one's own determination (or will-to-power) in order to ensure that the other does the same. My primary issue with this sense of freedom is that it merely entails respect for the other, not the other's well-being; it is an autonomous freedom and not a collectivist one. With property rights as its groundwork, it only requires that I respect the other's self-determination, not that I need to work with the other or ensure the other's welfare as I may wish the other to do with me. This concerns the notion of academic freedom since, given the current political climate, freedom often means a withdrawal from existing communities and societies - either with academics entrenching themselves within the university system to protect their research, teaching positions, and so forth from being co-opted by outside politics, or with the aforementioned examples of freedom employed 
within the Brexit and religious freedom debates. Thereafter I argue that freedom must be unfolded or perhaps redeveloped to something beyond Hegel's mere respect and recognition. The upshot is a possible future concept of freedom that is not based upon recognition and responsibility, but one on solidarity and obligation. However, this paper will only problematize the issue and cannot, due to the space and scope of the paper, immediately resolve the question of freedom in the South African university. I cannot imagine that one paper could immediately resolve this issue. Hopefully and however, I foresee that what follows may reshape the discussion of academic freedom within this context; questioning and spurring academics to further engage (rather than retreat from) the freedom debates that are happening in this country and in the world at large.

\section{HEGELIAN FREEDOM: PROPERTY AND RECOGNITION}

To understand what freedom is we must go back to its Western, modern roots in the philosophy of Hegel. However, given that our present concerns are an extension of Hegel's philosophy and not with Hegel himself, this review will only briefly (and perhaps simplistically) cover his concept. It should give us a foothold into the question of freedom itself, basically, and ought to illuminate and not overshadow our conversation on academic freedom in South Africa.

Hegel begins with a notion of freedom that moves from the abstract to the concrete through three forms: universality, particularity, and individuality. In the universality, one begins understanding oneself by consciously being aware "of itself to itself"; meaning that one recognizes that it exists in the world. But this freedom, being speculative and abstract, knows no limits to itself in relation to another: “(i) I am completely determined on every side (in my inner caprice, impulse, and desire, as well as my immediate external existence) yet (ii) nonetheless I am simply and solely self-relation, and therefore in finitude I know myself as infinite, universal, and free" (Hegel, 2008:53-54, §35). This universality is an abstract right that provides the conception that one exists in the world, yet, knowing oneself as infinite and completely unburdened (free), the expanse of one's determination flows over everything: one over-determines others in expressing this freedom and thus cannot co-exist with others or, as Hegel argues, one requires more in order to "be a person and respect others as persons," which he finds is the basic imperative to one becoming a personality (Hegel, 2008:55, \$36). As Charles Taylor puts it, "The intuition of genuine universality in man therefore progressively separates him from his community. It leads to a struggle within man and within the community as this public expression of the universal enters into conflict with every vocation to the universal which underlies it" (Taylor, 2005:172). Accordingly, this state of freedom must pass away in order for the self to enjoin its freedom to a community of others who wish to do the same.

\footnotetext{
$1 \quad$ For the remainder of this article I will cite both the page numbers of this translation and the section numbers for those using other editions.
}

The antipode to the universality is the particularity, where one finds its personality through its immediate desires and impulses; whereas the universality is an indeterminate state of 'everything and infinite,' the particularity is a determinate state of 'something and finite'. Hegel calls this an abstract right as well since it remains only concerned "with the person as person, and therefore with the particular ... only insofar as it is something separable from the person and immediately different from him" (Hegel, 2008:59, \$43). Here, the self's particularity is a slave to its immediate impulses and concerns in contradistinction to the universality's lack thereof. Universality and particularity therefore represent opposing aspects of one's freedom: in the universal, one finds oneself as an existing self but with nothing to show for its existence since this selfhood is infinite and expansive, and, in the particular, one finds oneself as an existing self through one's desires and impulses but cannot move beyond these desires to understand itself in relation to the whole. These are 'negative' forms of freedom since both find the self separated and hence the self denies any otherness so as to remain free from others (Hegel, 2008:2830, §5; Houlgate, 1991:75-82). Hegel has presented us with a dialectic of abstract freedom: on both sides the self remains an abstract concept, only willing to understand itself and its freedom in an absolutised form that either over-determines or under-determines itself, separating itself from others. What is required then, is a synthesis through the sublation (aufheben) of the two; forming the concept of the individuality.

Universality and particularity were abstract notions of the self's personhood and its freedom. Consequently, they were also immediate concepts of freedom. ${ }^{2}$ Contrariwise, individuality, in its self-determination, passes through a mediation where it finds itself face-to-face with another self. In order to respect this other one must limit oneself by neither over-determining this other (through the exertion of its own will) nor being overdetermined itself by the other. In this limitation, the self still knows itself (universality, indeterminacy) and also knows its desires and impulses (particularity, determinacy) but finds a way to be "both of these at once" through the sublation of the two, creating a "concrete concept of freedom, while the two previous moments have been found to be through and through abstract and one-sided" (Hegel, 2008:33, \$7). Rather than indeterminate or determinate, this process is best expressed as a self-determination in that it determines the self's personhood by requiring another self. Because of this requirement, it is a mediated determination.

Now that Hegel has an abstract concept of the self, he is ready to move towards understanding how freedom becomes a concrete reality through individuality. In doing so, he traces the history of Western freedom by beginning with the master and slave dialectic: the master frees himself/herself from

2 Given the scope of this article and the brief, and my somewhat overly simplistic reading of Hegel, we do not have time to review the question of immediacy and mediation within Hegel's thinking. However, for clarification, see Pippin, Robert, Hegel on Self-Consciousness: Desire and Death in the Phenomenology of the Spirit (Princeton: Princeton UP, 2012) Ch. 2, "On Hegel's Claim that 'Self-Consciousness Finds Its Satisfaction only in Another Self-Consciousness." 
the burden of labour by enslaving the other. Yet the master's freedom is imperfect: since the master comes to depend on the slave, the master consequently fails to achieve the robust, concrete autonomy of self-determination (Hegel, 2008:44-57, \$25-41). Skipping ahead in the development of concrete forms of freedom, Hegel reaches a stage where individuals mutually relinquish certain freedoms (like the freedom to kill or enslave another), and thus they create a space of mutual recognition where each sees the other as an individual self (Hegel, 2008:49$52, \$ 32)$. Here, each side's recognition begins with a respect for the other's property, hence, "from the standpoint of freedom, property is the first existence [Dasein] of freedom;" i.e. this is its first concrete existence (Hegel, 2008:61, \$40). More pointedly, the moment that property is recognized by two individuals is the first moment where one's personhood becomes more than an abstract notion: "the rationale of property is to be found not in the satisfaction of needs but in the supersession of pure subjectivity of personality. In his property a person exists for the first time as reason" (Hegel, 2008:58, \$41) ${ }^{3}$ Property is the first concrete understanding of freedom and this is because of its rationality. As Merold Westphal clarifies, this rationality transcends the "subjectivity of personality" since, by owning property, the self begins its concrete existence (i.e. the self is no longer an abstract concept) because property gives the self a tangible, physical realization of its selfhood (Westphal, 1992:29). Property represents the self's claim to exist in the world saying, as it were, 'here I am, this is my land, and I will defend it either through the courts or through battle'.

In safeguarding this respect, individuals come together to enact laws and declare certain inalienable rights. This coming together creates a 'we,' a society of self-determining individuals, living together, who all enjoy the same freedoms but also share responsibilities of protecting the rights of others. For Hegel, property is merely the first concretization of this mutual respect between individuals and he argues that all laws and rights thereafter are extensions of this initial respect. Thus, at the beginning of the question of freedom is a question of recognition, of limitation of one's selfhood in order for another literally to exist in space and time. Note that this concretization happened before humanity historically created land deeds and contractual law; these are just progressions of this movement toward freedom: what is actually at issue here is the mutual recognition that 'this is my space' and 'that is your space' begins the quest for understanding how one becomes free in the world. Our eventual movement toward laws and rights further establishes these claims, thereby building a more robust concept of freedom within a society.

In summary, Hegel's concept of freedom is entrenched into his idea of how one even becomes a self, how one may even claim to have free will. Beginning with one-sided and abstract notions of freedom and personhood, he argues that the self initially sees itself as, on the one hand, an infinitely existing thing that is unburdened by any limitations. On the other hand, through its slavish desires and impulses, the self also sees itself as finitely bound to the particularities of these impulses. On both sides, one cannot find a true and actual sense of freedom within the world; both constructions are abstract and cannot deal with any sense of alterity or otherness (and, hence, any mediation). In order to find a way to deal with alterity, the self recognizes other selves a qualitatively the same, thereby limiting both sides of abstract freedom (each is aufgehoben into the other) to create a self-determined identity: the self's infinitely expansive existence cancels out its finite and particular desires, and both are elevated to a sense of identity that, through a mediated existence with others, is able to freely express itself by not over-determining others nor being over-determined itself. The first moment of this self-limitation begins when the self recognizes its own property, its own place in the world, while also recognizing that others have this same ability. To solidify this recognition, these individual selves come together to enact laws and rights, which begins a society and the conversation about what else should become a law or right.

\section{AUTONOMOUS FREEDOM: THE PROBLEM WITH PROPERTY}

Hegel conceptualizes freedom as a part of our personhood and, by extension, how we see others. Hegel's concept is a sound one and its influence can be seen (whether intended or not) within the constitutions of most democratic governments. One can see it, for example, within the Constitution of the Republic of South Africa (1996), where it defines who can be recognized as citizens and what rights and privileges are citizens are endowed with: "There is a common South African citizenship [i.e. we recognize that we legally are bound together]. All citizens are (a) equally entitled to the rights and privileges of citizenship [i.e. we recognize that all have qualitatively the same selfhood] and (b) [are] equally subject to the duties and responsibilities of citizenship [i.e. they must recognize that others have this selfhood and are duty-bound to uphold it]." 4

One can also see it within the question of academic freedom: the university, as an institution, claims its freedom to be separate and individual from other institutions (explicitly, the state) by asserting its rights and privileges to self-governance. Thus, it concretizes its own self-determination by claiming these rights, the right to exist. Effectively, the university claims, 'this is our space.' In order to make this freedom and individuality clear, it drafts a charter for itself, a contract, which eventually is mutually recognized by its board of trustees (as well as those who are a part of the institution, the faculty especially) and the state, along with other socially important institutions. The university, in the interests of pursuing its goals as an institution (as stated in its personal charter), seeks recognition by the state as a free and separate institution. The state, as a product of the people, seeks to educate those people and notices that a university that is free to achieve its own interests (i.e. achieve its own self-determination, its own freedom) is mutually beneficial; even if at times the state subsidizes the university's research and tuition. Therefore, the university restricts itself to remain within its stated charter (its self-determination) and the

4 Constitution of the Republic of South Africa, 1996, ch. 1, art. 3, sect. 1-2. 
state recognizes its independence. Academic freedom, in this mode, is one of mutual self-interest and autonomy that begins with the actualization of the institution as a self-determined entity with the right to exist independently that is then recognized by its other, which in this scenario is the state.

This concept of freedom therefore allows the university to remain solely on its own in the name of its academic freedom. The state recognizes this freedom, so as long as the university upholds its side of the bargain to educate the state's citizenry and to have its research spur economic and social development; as long as this relationship is mutually beneficial, basically. Accordingly, when the state or other institutions begin to interfere in the university's operations, academics (as part of the university) fight for their right to this freedom. ${ }^{5}$ This is often where the question of academic freedom lies for most people: on whether the state (or other actors) has the right to interfere in the university's operations, often on the level of dictating what it should (or should not) research and teach to its students.

The interference in the university's right to self-determination is indicative of a much larger issue concerning whether this notion of freedom is even the most beneficial one for humanity as a whole. Does it enable, rather than limit, our more selfish desires by propagating a system that furthers our own autonomous will-to-power? Is this concept of freedom the most 'just' concept that we can create? On a societal level, the university is more than an institution that is autonomous from the state. As mentioned before, academics push society to question and re-evaluate the world in which society creates and, in turn, the larger society pushes academics to remain grounded by addressing the extant questions and concerns that they have of that world. Both, then, need each other for existence but not in a way where one recedes so that the other can be, nor in a way where merely recognizing the other is satisfactory. Rather, the issues academics investigate stem from the problems society itself is grappling with and, in turn, the possible solutions that academics find spur society onward, thereby creating more relevant questions. Furthermore, since academics are themselves a part of society and universities often exist within the functional apparatus of the state - as funded by the state - they cannot extricate themselves from the larger whole and hence claim true independence from it. If these statements are true then this relationship goes beyond mutual recognition and self-limitation: it becomes an issue of heteronomy and interdependence, not one of autonomy and individuality. Even though Hegel recognizes that mediation is necessary for selfdetermination (there need to be other selves for one to be a true self, basically) his concept of freedom sidesteps the underlying issue of obligation by merely beginning with property rights as its first and, consequently, necessary embodiment.

$5 \quad$ Even though 'the state' has been used for the university's other in this explication of freedom, one could easily introduce other institutions into this role, or perhaps collective groups such as protestors who represent a certain aspect of society. The concrete way that universities achieve their freedom varies according to the sociopolitical constructs of the society in which they exist but the general idea of how they achieve this freedom still fits Hegel's concept.
Also, a side issue emerges concerning private universities that further challenges this model of freedom: because of their independence from the state they are often awarded 'more' freedom than state universities, especially when it comes to enrolment and curricula. The question of concrete academic freedom becomes fragmented and more particular as the types of freedom enjoyed by institutions are often dictated by their relation to the state and society at large. This furthers the need for a better understanding of freedom beyond Hegel's concept: do private institutions deserve more freedom than state-run ones? Though their charters often declare a similar mission to educate and uplift society, are they less bound to the concerns of society? Hegel's concept of freedom accords private universities greater freedom, so the respective answers are yes, they have more freedom than state-run institutions, and no, they are not bound to the concerns of society. Yet still, there is a glitch: many states subsidize tuition fees and research at private institutions and these institutions, comprising academics who exist within society, who still claim to uplift and educate that society, thereby creating a link between their research and teaching and society at large. They see their work as important to society. In both cases they represent a concept of freedom that exists in between sole autonomy and freedom; they are connected-thus-obligated but they are also separatethus-independent. Considering the religiously confessional nature of many of these private universities, their concept of academic freedom is further problematized by their respective adherence to religious doctrine and how it influences their curricula and student formation. All of this necessitates a need to better understand the concept of freedom amidst conflicting obligations.

Returning to the core issue, Hegel has presented us with a concept of freedom that is essentially self-interested and sees others only as necessary functionaries employed to preserve this self-interest: the only reason I respect others' property and abide by the laws of society is ensure that others do the same. ${ }^{6}$ Autonomy becomes the name of the game and if all that I need to do is restrict some of my self-interested impulses in order to achieve most of my desires then this is a bargain that I can live with. This limitation becomes the standard by which we treat others and, though it is a necessary one, it is also not enough. As Merold Westphal points out:

6 I concede that this is a somewhat Fichtean reading of Hegel, but I think that this point is still a valid one. Though Hegel is trying to present us with a description of how freedom is realized and not what freedom ought to be, I find that, by describing it as beginning with property, he lays the foundation for every encounter with an other to be one of self-interest, even if one has to limit one's self-interest in order to not over-determine this other. In Fear and Trembling's teleological suspension of the ethical and Concluding Unscientific Postscript's theory of stages culminating if a Christ-like love for the other (which is later elaborated upon in Works of Love) Søren Kierkegaard levies a similar critique against Danish Hegelianism. For more regarding this issue, I have covered this critique and how Merold Westphal employs it in how own concerns against Hegel: Sands, Justin, "Hegelians in Heaven ... But on Earth? Westphal's Kierkegaardian Faith," Journal for the History of Modern Theology, 23(1) 2016, 1-26. 
The property I own may be far from sufficient to provide for my subsistence needs; and my property rights will not have been violated as long as I own something. The society that refuses to bulldoze the shanty town in which I live so as to respect my rights as a 'homeowner' will have done all that is required by Hegel's theory of property rights, even if it provides me with no work or with work at wages so low that I cannot feed and clothe my family (Westphal, 1992:25).

Westphal's argument is that perhaps freedom requires more than the respect and separate spheres of action for individuals. ${ }^{7}$ Going back to the Louvain scenario, these professors acted within their rights and freedoms, as prescribed by Hegel and within Belgian law, to divide their university. However, in doing so, they also failed their mission towards the society which created, sustained, and above all needed them. Although Hegelian freedom enjoins a respect between individuals within society, it can also be used to separate society; the 'we' disintegrates in light of so-called 'respect' when one wants to exert their right to autonomy from others. To be fair to Hegel, a society can build on to this issue of respect to provide rights that are more than property rights - such as the right to clean drinking water in the Constitution of the Republic of South Africa or the right to an attorney at trial in the U.S. Constitution. This is the beginning for Hegel, not the end point. Yet still, by initializing the first moment of intersubjectivity and all concrete forms of freedom with a basic self-interest for recognition through possession and property rights, Hegelian freedom becomes foundationally a conceptual desire for an autonomous existence in light of a world populated with other selves. Though there is a duty and responsibility to respect other's autonomy, this is still selfinterested: it is a contract between two selves to not attack the other's possessions.

\section{CONCLUSION: UNFOLDING FREEDOM}

Freedom, in particular academic freedom, must demand more than just a respect for society. The concept of academic freedom unfolds through the relationship between the university and society, but, in order for that unfolding to occur, there must be a sustained engagement between them. A university's mission accordingly cannot be the pursuit of autonomous self-determination; it is a pursuit to educate and uplift its students and, thus, its society. In this way, its freedom cannot be separated from society; it must listen to the concerns within society and seek resolution for those concerns. In our current situation, where protests are a regular occurrence, academics should not shut their office windows to quiet the anguish and cries from those outside. By further separating itself, the university loses its ability to speak on these issues, thereby ceasing to progress both society and itself. It dies a slow death of irrelevance due to its own autonomous desires. Covalently, protestors cannot expect the university to address these issues if they do not respect the university's historical-cultural situation

As an American born in The South who has had to live with the legacy of Jim Crow as the next embodiment of freedom after slavery for black men and women, this is something I recognize well. Perhaps South Africans do too within the history/legacy of apartheid.
- research and education is the hard boring of hard boards and the university cannot capitulate to the immediate changes of the times. Doing so negates the thoughtful processes and goals embedded within the university's mission.

With regard to the language debate and the larger issue of racial transformation within the university system, this means that academics must seek to understand the concerns governing the changes within society. Is the language debate similar to Leuven's? Definitely not, given the distinct histories of Belgium and South Africa, but South Africans should definitely not hope for the same outcome. Therefore, South African universities must not use their academic freedom to combat societal changes seen in 'Afrikaans must fall' and so forth, it must seek to uncover what is really going on: do people really detest Afrikaans or has it come to represent an undercurrent of historical injustice and neglect? If the latter, then universities must tangibly respond to those afflicted through systemic changes. However, merely accommodating society through changing official languages only meets Hegel's definition of freedom; it does nothing to satisfy the underlying cries and anguish behind the protests. It must do more - it must unfold the concept of freedom once again - in service of the community with which it is entwined through evaluation, critique, and education. In this way, academic freedom does not entail autonomy. It requires something more, perhaps even a new concept of freedom that does not disintegrate into an individual will-to-power. This unfolding can either move toward the university breaking apart from society, or it can collectively pool its resources by pulling academia and society even closer together.

I envision that engaging society on the question of freedom academic or otherwise - will resultantly become an engagement with how individuals, collectives, and, on an international level, how states perceive their own independence from their respective others and, accordingly, their obligations. The Brexit issue, upholding the European Union (or even multi-national treaties such as NATO), and the US religious freedom debates are pertinent pressure points that essentially question how one conceives of one's own freedom and, by extension, via Hegel, how one conceives of self-determination. The academic community is already researching these questions but, at times, it fails to see that its own grappling with academic freedom is connected to these concerns. If academics were to merely exert their own autonomy, in the name of 'solving' these social issues, then is it not already making a political statement before it even presents its research? By claiming such autonomy, academics have already made a stand on the concept of freedom itself. Hypothetically, if a professor teaches and publishes that society needs to be further engaged with others, to become a tighter 'we' in solidarity, then he or she has essentially carved an exceptional space for themselves. Understanding that the question of academic freedom pertains to the larger concept of what freedom is to society is an essential, but often forgotten, step.

What I have carved out above is a critique of Hegelian freedom and its underpinning of the basic concept of freedom for both the Western and South African societies. I also localized the investigation by looking at academic freedom within 
the South African university system. What I have not done is propose any remedies for the essential problematic that Hegel conceptualizes freedom as beginning with property and, hence, beginning with self-interest. I have intentionally left this question open-ended because I foresee a larger and perpetual conversation between academics and society concerning what our so-called independence from others actually means. However, as one can see within my critique, I find that the primary movement will be toward more engagement between others, not more autonomy from others. One could perhaps see the seeds of a discussion between Levinas, Habermas, Kierkegaard and others who explore intersubjectivity and its relationship to autonomy and obligation, and ultimately to ethics. Freedom, in this vein, becomes not just an ethical act but a political one. I anticipate a great, but heated and enduring, discussion.

On a concluding yet open-ended note, one might object that South African society is not solely defined by Hegelian freedom. This is certainly a fair objection. But, just before entering the Apartheid Museum in Johannesburg, I was instantly confronted with seven obelisks that represented the "seven fundamental values" or pillars of the new (1996) South African constitution: democracy, equality, reconciliation, diversity, responsibility, respect, and freedom (The Apartheid Museum, 2016). I cannot help but see Hegel's influence within the final pillars of responsibility, respect, and freedom, especially after looking at the constitution itself. This is anecdotal, to be sure, but this monument is a monument for a reason: it is a testament of South Africa's present and hopeful future just before one enters into its past throughout the museum. By adding four more pillars to the Hegelian three - democracy, equality, reconciliation and diversity - South Africa has already begun to see the issue with beginning understanding itself through mere responsibility, respect, freedom and so forth. Perhaps this acknowledgement of their forward-looking present, before regarding its past, is why this country is poised to question the nature of freedom once again from both a local and global perspective.

\section{DECLARATION OF CONFLICTING INTERESTS}

The author declares no potential conflicts of interest with respect to the research, authorship, and/or publication of this article.

\section{FUNDING}

The author received no financial support for the research, authorship, and/or publication of this article.

\section{BIBLIOGRAPHY}

The Apartheid Museum. 2016. The pillars of the constitution. http://www.apartheidmuseum.org/pillars-constitution Date of Access: 29 Aug. 2016

Hegel, G.W.F. 2008. Outlines of the philosophy of right. Trans. and Ed. by Stephen Houlgate. Oxford: Oxford University Press.

Houlgate, S. 1991. Freedom, truth and history. London: Routledge.

Pippin, R. 2012. Hegel on self-consciousness: Desire and death in the phenomenology of the spirit. Princeton: Princeton University Press.

Sands, J. 2016. Hegelians in Heaven ... But on Earth? Westphal's Kierkegaardian Faith. Journal for the History of Modern Theology, 23(1), 1-26.

South Africa. 1996. The Constitution of the Republic of South Africa.

Taylor, C. 2005. Hegel. $17^{\text {th }}$ ed. Cambridge: Cambridge University Press.

Westphal, M. 1992. Hegel, freedom, and modernity. Albany: SUNY Press. 